\title{
Public Perception to Covid-19 Outbreak: Study of Mysticism and Spirituality Shalawat Simtu al-Duror
}

\author{
Ahmad Mujib,1 Muna Yastuti Madrah,2 ${ }^{2}$ Abdul Aziz, ${ }^{3}$ Nailil Muna ${ }^{4}$ \\ 1,2,3,4Universitas Islam Sultan Agung Semarang-Indonesia \\ e-mail: 1ahmad.mujib@unissula.ac.id; 2munamadrah@unissula.ac.id; \\ 3aziz080594@gmail.com; ‘naililmuna@unissula.ac.id
}

\begin{abstract}
The Corona Virus pandemic has created policies to foster people to stay healthy and free from this disease. However, there are groups of people who ignored the covid-19 protocol for some mystical and spiritual reasons. This study taking place in Mranggen central java, observing the Majlis shalawat of Jalatunda. The congregation of zikr and prayers of Jalatunda believe that the shalawat of Simtu al-Durar may avoid all kinds of diseases. The value of mysticism strengthens the spirituality of the congregation. We use a phenomenological approach to describe and explain each variable into material for analysis. This study found that the mysticism that exists in public belief has become a vehicle for the practice of reciting shalawat which further improves the spirituality of the congregation of the assembly.
\end{abstract}

Keywords: coronavirus pandemic; mysticism; spirituality resilience; shalawat simtu al-durar

\section{A. Introduction}

Many countries responded to the spread of Corona Virus Disease (Covid-19) fastly. Most countries advocate a health protocol which is wearing a mask, keeping physical distance, and washing your hands. The pandemic has changed the fabric of people's lives. Access to social interactions is limited, this is related to the implementation of health protocols. This has an impact on individual life as well as social society in communal activities.

In response to this situation the government issue various policies in all fields, both to prevent the spread of the virus, as well as to mitigate the economic, social, cultural, and political impacts that accompany the pandemic situation. However, the various perceptions of the community in responding to the Covid19 outbreak were very diverse. There are also a group of people who do not believe that covid-19 is a dangerous disease. They even thought it was just a kind of common cold, and there was nothing to worry about. This interpretation 
ultimately causes all government policies to be responded to differently by the public.

The diversity of social, cultural, and religious characteristics amongst communities causing different interpretations of reality. Values that the community believes controlled them to act as the information circulating. It is mostly found in traditional society. Society still believes in mystical elements. One of the examples can be seen in Javanese society. Many Javanese mixed the Islamic value and mysticism in their daily life. The mysticism of Javanese and the value of Islami mixed and create unique distinctive characteristics of Javanese Islam. Traditionalism and mysticism in religious societies are often difficult to separate. Religion is characterized as something traditional and mystical and is contradictory to modernity which is based solely on rationality. ${ }^{1}$

Mysticism in Java has existed since the Hindu-Buddhist era until today. The entry of Islam in that phase has created the acculturation between Islam and the previous belief. Those created seeds of Islam that are full of mystical values. The second last stage of Islamic development, the phase of ideology and ideas is the modernization of the result of dialectics with the social conditions of society which were also influenced by European civilization. ${ }^{2}$

Muslims in Indonesia are very dynamic. However, in substance, the symptoms of the old teachings from the ancient are still visible in society. Clifford Geertz $^{3}$ in his long research in java stated as the religion of java. He anthropologically categorized Javanese society into three groups, which are, abangan (ordinary Muslim), santri (religion-educated Muslim), and priyayi (aristocratic-educated-Muslim). This categorization is still used as a reference in discussing Muslim society in Java today. The santri and priyayi, are groups that still maintain a lot of Islamic mystical teachings. Such a view raises problematic sides such as dogmatism and fatalism. These two phenomena are realities that are often contradicting pure rationality, which is a feature of modern civilization. Mysticism is still something important as one of the constructions of civilization, which is

1 Muna Yastuti Madrah, Nailil Muna, and Tali Tulab, "Pandemik Dalam Masyarakat Risiko," Wahana Akademika 8, no. 1 (2021): 57-69.

${ }^{2}$ Kuntowijoyo, Dinamika Sejarah Umat Islam Indonesia (Yogyakarta: Pustaka Pelajar, 1994).

${ }^{3}$ Clifford Geertz, Priyayi Dalam Masyarakat Jawa (Bandung: Dunia Pustaka Jaya, 1981). 
sometimes able to balance between anthropocentric and theocentric sides, rationalism with humanism, profane with sacred, and positivism with spiritualism. ${ }^{4}$

This article discusses how people with mystical cultural systems responded to the Covid-19 outbreak. The study was conducted on Muslim groups who are members of the majlis Zikir and Shalawat of Jalatunda in Sumberejo village, Mranggen sub-district, Demak district, Central Java.

Using a symbolic interactionism-phenomenology approach, this study explains the values that underlie the congregation members of majlis zikir and shalawat of Jolotunda that have contradictory perceptions of the general discourse about the Covid-19 outbreak. This perspective leads to the idea that human practices should be seen as a process that enables humans to regulate and shape their practices with the considerations and expectations of others with whom they interact. The meaning they give to other people, objects, or even themselves determines their practices. ${ }^{5}$

Religion still requires a symbol system. In other words, religion still needs religious culture. Religion without culture can still develop as a personal religion, but without culture, religion as a collectivity will not have a place. ${ }^{6}$ Humans tend to be united by symbols embodied by language, art, and others. In this perspective, the rite system in the religious aspect is seen as a symbol that characterizes communication. The phenomenological approach of symbolic interactionism helps to analyze the reality of religious societies. ${ }^{7}$

\section{B. Mysticism and Spirituality}

Mysticism developed in parallel with religious institutions. Mysticism is one of four aspects of religion, which are magic, membership, morality, and mysticism. The four aspects are perceived as the way to salvation. By following them, a

4 Umer Chapra, Peradaban Muslim: Penyebab Keruntuhan Dan Perlunya Reformasi (Jakarta: Amzah, 2010).

5 Deddy Mulyana, Metodologi Penelitian Kualitatif(Bandung: Remaja Rosdakarya, 2004).

${ }^{6}$ Kuntowijoyo, Muslim Tanpa Masjid (IRCiSoD, 2018),

${ }^{7}$ Morissan, Teori Komunikasi Individu Hingga Massa (Jakarta: Kencana Media Group, 2013).

JURNAL THEOLOGIA — Volume 32, No. 1, Juni 2021 
person is believed to be able to find safety in his social and personal life. ${ }^{8}$ Mysticism has an important role in human life, especially among religious people, however, there is a debate in terms of terminology and its existence.

Mysticism is part of a specific and unique religious experience that attracted the attention of many scholars. Wainwright ${ }^{9}$ was interested in discussing mysticism because of the large amount of mysticism literature that discusses religion. These works of mystical literature (suluk) spread all over Java Island and continue to influence the politico-religious term. Such as the term of manunggaling kawulo gusti which has replaced the concept of devaraja which had developed in Java previously. The concept of devaraja believes that God assumed to come down temporarily from heaven to inhabit the human body. This doctrine developed in Indonesia through Sufism and mysticism. This concept teaches that every human being who practices and performs pious contemplation will receive the gift of closeness to God. However only kings receive this divine dignity. People get this divine blessing symbolized in the name of the king, a special date, the hierarchy of the king and the people, enshrined in inscriptions, dance, traditional ceremony, carnival and is disseminated continuously in wayang kulit performances. ${ }^{10}$ The development of mysticism in Indonesia did not only revolve around the palace but also spreads among ordinary people, such as Subud and Sumarah as studied by Geels ${ }^{11}$ and Stange. ${ }^{12}$

In Islam, mysticism is often called Sufism, a term that excluded all forms of mysticism practised by other religions. ${ }^{13}$ According to Findlay ${ }^{14}$, all forms of mysticism including doctrine, practice, and experiences of ecstasy have consequences for the practitioner's self-identity in the search for the highest mystical unity. Sufism is a form of awareness through which communication and

\footnotetext{
${ }^{8}$ Randal Collins, "H. Paul Douglas Lecture the Four M’s of Religion: Magic, Membership, Morality and Mysticism,", Review of Religious Research 50 (2008).

${ }_{9}^{9}$ Sufisme Jawa Transformasi Tasawuf Islam Ke Mistik Jawa Simuh, Sufisme Jawa Transformasi Tasawuf Islam Ke MistikJawa, 2nd edn (Yogyakarta: Bentang Budaya, 1996).

10 Rachmat Subagya, Agama Asli Indonesia, 1stedn (Jakarta: Yayasan Cipta Loka Caraka, 1961).

${ }^{11}$ Antoon Geels, Subud and the Javanese Mystical Tradition (Richmond, Surrey: Curzon, 1997).

12 Paul Stange, Kejawen Modern: Hakikat Dalam Penghayatan Sumarah (Yogyakarta: LKiS, 2009).

13 Harun Nasution, Falsafat Dan Mistisisme Dalam Islam (Jakarta: Bulan Bintang, 1995).

14 John Findlay, “The Logic of Mysticism,” Religious Studies 2, no. 2 (1967): 153.
} 
dialogue can occur between the human soul and God; it is often promoted through self-isolation and contemplation. ${ }^{15}$ Sufism is generally understood as asceticism a universal mystical tendency based on the rejection of worldly life. and intended to establish a relationship (ittisāl) with God, the source of everything; goodness, radiance, and illumination. In Lie's view, this "mystical union" was active. ${ }^{16}$ This is a religious practice in which the faithful take a more active and dynamic role in seeking union with God. As mysticism is deliberate practice, and therefore an understanding of mysticism must also be linked with a clear explanation of the steps mystics have to take. ${ }^{17}$

Meanwhile, spiritual in the language is taken from the Greek word spiritus which refers to a concept of the breath of life, understood as the air or subtle vapour that animates the organism. Spirituality has a substantial meaning, character, and essence of the human soul. This characteristic underlies the relationship between humans and God. Initially, religiosity and spirituality were equated. However, later on, spirituality has been considered as a special character and belief that are more personal, less dogmatic, more open to new thoughts and various influences, and more pluralistic. 18

Spirituality is marked by the enthusiasm and passion of the community to participate in various spiritual activities. For example, entering a certain group and some leaving the sparkling world life. If it is connected to the magical and mystical elements by reading a mantra or certain recitation. They believe, it can avoid all diseases and dangers, get safety, get the blessing of life, and so on. Such characteristics have been shown by some groups of people, where spirituality becomes an important requirement for certain communities, especially in Java. 19

Piedmont ${ }^{20}$ defines spirituality as a series of motivational characteristics (motivational traits), general emotional forces that drive, direct, and choose a

${ }^{15}$ Nasution, Falsafat Dan Mistisisme Dalam Islam.

16 Muhammad Fauqi Hajjaj, Tasawuf Islam \& Akhlak (Jakarta: Amzah, 2011).

17 Halie Daniel Lie, "Analisa Kritis Terhadap Pandangan Unio Mystica Ditinjau Dari Teologi Perjanjian Baru'," Veritas 2, no. 3 (2001). 2006).

18 Holt BP, Thirsty for God: A Brief History of Christian Spirituality (Minneapolis: Fortress Press,

${ }^{19}$ Koentjaraningrat, Kebudayaan Jawa (Jakarta: Balai Pustaka, 1984).

${ }^{20}$ L Piedmont, Teresa A Wilkins, and Ralph L, An Epistemological Approach to Understanding Spirituality and the Numinous, 1st edition (New York: Routledge, 2019).

JURNAL THEOLOGIA — Volume 32, No. 1, Juni 2021 
variety of individual behaviour. In community religious practice, spirituality at its peak of vision and insight into reality is achieved through the stillness, spaciousness, and clarity of the soul. Spirituality is an ontological-epistemologicalaxiological commitment to interpreting reality as real as it is, without being exaggerated or reduced. It is a way of exploring the ocean of diversity holistically and comprehensively so that the interconnection, interdependence, and interrelation between entities vertically and horizontally.

Spiritual experiences encourage people to find common ground instead of looking for differences. This is also shown by the practitioners of the shalawat of Simtu al-Durar. They tried to harmonize all forms that seem different or even contradictions. It is to show the balance of nature with the belief that nature moves in a controlled manner by the will and power of God. Such belief gives rise to a Sufistic character in which there is a subjective experience. They seem to have no difficulties finding arguments related to what is happening in the world, in this case, the Covid-19 pandemic that has hit the world.

\section{Shalawat Simtu al-Durar and Spirituality Resilience}

Shalawat is literature that contains praise, the history of the life of the Prophet Muhammad. ${ }^{21}$ The shalawat also contains a message of wisdom that has a depth of meaning and spirituality. In the system of creeds and rites that exist in Islam, shalawat has an important role. Shalawat is always related to the religious activities of Muslims. Islam places ethics and aesthetics in praising the Prophet, as the saviour for all mankind. In all conditions, even in crisis and dangerous situations, a Muslim, in Islamic teachings, advised to always recite shalawat continuously, including in this pandemic situation. ${ }^{22}$

In the Qur'an, the proposition of shalawat is found in Sura Al-Ahzāb verse 56, where it is explained that Allah and His angels pray (do shalawat) to the Prophet Muhammad. Shalawat here means, if it is from Allah, it comes in the form of glory and mercy. If it is from the angels, shalawat comes in the form of a request for glory and mercy to Allah. Meanwhile, from humans, shalawat is prayer and glorification of the position of the Prophet. ${ }^{23}$ These expressions are the same as prayers and

\footnotetext{
21 Umi Azizah Khalil, Shollu 'Alan Nabi (Yogyakarta: Araska, 2020).

22 Sayyid Muhammad Alawiy, Jala'u Al-Afham Syarh 'Aqidah Al-'awam, 2004.

${ }^{23}$ Muhammad bin Ahmad Al-Qurthubi, Al-Jami' Li Ahkam Al-Qur'an, Jilid VII, vol. VII (Kairo, 2010).
} 
adulation to the Prophet. ${ }^{24}$ Fakhrudin Al-Rāzi explained that shalawat to the Prophet was not based on the basis that the Prophet needed it, but a form of confirmation from Allah that he (Muhammad) was a noble figure and he would reward anyone who glorified him. This is also explained by Al-Baidlowi in his commentary. ${ }^{25}$

The tradition of shalawat in Indonesian history is very diverse. This is related to a very diverse culture. The tradition of shalawat has been widely adopted into the culture of local communities in Indonesia. This indicates that the values of Islam and local culture are not in a position of facing each other but in collaboration and acculturation. Over time, the tradition of shalawat has also crystallized into the identity of the Indonesian nation. ${ }^{26}$

The tradition of shalawat in Indonesia is generally practiced in a colossal form. They gather in an assembly to recite shalawat together and close it with the speech by religious figures or leaders. The tradition of reciting shalawat in Javanese society, for example, is understood by reciting different types of shalawat related to the purposes. For example, for the seventh month of pregnancy (baby shower) and marriage usually, recite shalawat al-Barzanji. For the event of moving houses they recite shalawat burdah In addition, there is also a group of people who do practice the tradition of shalawat as a routine and specifically recite certain types of shalawat.

Shalawat is not just reading dua, but also prayers in various rituals of life. By recite shalawat to the Prophet, a person hopes that what he or she wishes will be granted by Allah, because they are the person closest to Allah. As stated by Sheikh Ismail Al-Hamidi, quoted by Sheikh Nawawi Banten in his book Käsyifah al-Sajā, regarding the purpose and meaning of shalawat. Some of the hadiths used by Muslims are the hadiths narrated from Anas r.a from the Prophet. Anas r.a said, whoever recites shalawat for me (Muhammad) once, Allah will reward them ten. Whoever recites the shalawat ten times, Allah will reward them a hundred. Whoever recites shalawat a hundred times, Allah recorded as a person who is

\footnotetext{
${ }^{24}$ Wildana Wargadinata, Spiritual Salawat (Malang: UIN-MALIKI Press, 2010).

${ }^{25}$ Fakhrudin Ar-Razi, Mafaatih Al-Ghaib, Jilid XXV (Beirut: Daar al-Fikr, 1981).

${ }^{26}$ Khalil, Shollu 'Alan Nabi.
} 
free from nifaq (a trait that refers to hypocrisy), free from hell, and places the Day of Judgment with the martyrs, HR Thabrani. ${ }^{27}$

As Zawawi's ${ }^{28}$ explained that if someone reads a shalawat in which there is a request to Allah to give mercy and respect to the Prophet, then Allah will reward the reader of shalawat in the form of ten times the mercy and respect for them. Likewise, in the prayer reading the shalawat there is a request for salvation to the Prophet, then Allah will reward the reader in the form of ten times the guarantee of safety for them. This value is the spiritual fortress of the shalawat congregation in facing all the dangers that threaten him, including in this case the danger of Covid-19. 29

Shalawat Simtu al-Durar has written by Habib 'Ali bin Muhammad bin Husain bin Muhammad al-Habsyi. He was born in Qasam, Hadramaut, Yemen, on Friday $1839 \mathrm{AD} / 1259 \mathrm{H}^{30}$ His father was Muhammad bin Husain bin Abdullah Al-Habsyi, and his mother was As-Syarifah Alawiyah bint Husain bin Ahmad AlHadi Al-Jufri, a figure who was known for his sholihah and very wise. Habib Ali is well known amongst scholars as a figure who has noble, generous, and intelligent characters in his knowledge. In Indonesia, his youngest son, Habib Alwi bin Ali AlHabsyi is well known and founded the Riyadh Mosque in Solo, Central Java. Besides, he also spread disseminated shalawat Simtu al-Durar in the Central Java region. Habib Ali died on Sunday, 20 Rabiul Akhir, $133 \mathrm{H}$. Throughout his life, he was very productive writing books, including Al-Jauhar al-Maknun wa al-Sirr alMashun, Al-Futuhhat al-Ilahiyah, and Simtu al-Durar, fi Akhbar Maulid Khair alBasyar wa Ma Lahu min Akhlaq wa Atsar wa Siyar ${ }^{31}$ Habib Alwi, who lived in Solo for a long time, had a son. To this day, the shalawat Simtu-al-Durar continued to recite by Habib Alwi's successor, namely Habib Ali bin Hasan bin Anis.

Habib 'Ali bin Muhammad bin Husain bin Muhammad al-Habsyi used the beautiful language style and emit the love to the Prophet which was full of joy, the book of shalawat Simtu al-Durar quickly spread all over Indonesia. Every Islamic

27 Sayyid Syarif Abdullah Muhammad, Al-Nafkhah Al-Ilahiah (Jakarta: Daar Ar-Raudha AlIslamiyah, 2018).

28 Zawawi, "Interview : Zawawi.”

${ }^{29}$ Alawiy, Jala'u Al-Afham Syarh 'Aqidah Al-'awam.

30 Muhammad Khalid Tsabit, "TarikhAl-Ihtifal Bi-Maulid Al-NabiShalla Allahu'Alaihi Wa Sallama Wa Madhahirihi Fi Al-'Alam” (Kairo: Daar al-Maqtham wa al-Nasyr wa al-Tauzi, 2010).

${ }^{31}$ Ali Husein Al-Habsyi, “Untaian Mutiara Kisah Kelahiran Manusia Utama: Akhlak” (Solo, 1992). 
religious ceremony, such as weddings, birthdays, childbirths, baby-shower people recites shalawat Simtu al-Durar. Habib Ali, the writer, once advised that anyone who continues reading this book of shalawat will receive blessings from the Prophet Muhammad. ${ }^{32}$ The book of the shalawat Simtu al-Durar is divided into several themes which contain the history of the Prophet in sequence in a prophetic period and age level. It also contains a lot of Islamic educational values such as faith, morals, worship, and social values.

Shalawat simtu al-Durar was first distributed through a ceremony (haflah) Maulid Akhir Khamis by Habib Muhammad bin Idrus Al-Habsyi in the Cirebon (west Java). It continued to several cities, such as Bogor and Surabaya. The last maulid was held at the Sunan Ampel Mosque in Surabaya (East Java) in 1919 AD, just a few months before the death of Habib Muhammad. At that time Habib Muhammad handed over to Habib Ali bin Abdurrahman Al-Habsyi Kwitang Batavia Centrum (Jakarta). This shalawat was officially disseminated by Habib Ali Al-Habsyi Kwitang in Jakarta in 1920 AD. The book was first to read at Habib Ali's residence. Then on the 12th of Rabiul Awal (the month of the Prophet's birthday), he read the book of Simtu al-Durar at the house of Habib Umar bin Hamid (his student). On the 27th of Sha'ban $1327 \mathrm{H}$, the prayers were read in front of the Prophet Muhammad's Tomb, Medina ${ }^{33}$.

Majlis shalawat Simstu al-Durar Jalatunda is one of the groups that practice shalawat until today. Majlis Jalatunda formed in 2014, in the village of Sumberejo, Mranggen District, Demak Regency, Central Java. Since the establishment of the group, Jalatunda has attracted the attention of the people around the area. The name of Jalatunda is taken from Arabic, Jalla turdha which means the most glorious. Mranggen itself is an area where the practice of Sufism is taught and carried out by religious leaders. There were several important figures, such as Hadi Girikusuma, ${ }^{34}$ Ibrahim Brumbung and Kiai Muslih. Since the 19th century, they have alternately been leaders of tarekat which have continued from generation to generation. This social setting indicates that the area has a very strong tradition of mysticism. This has also been proven by the emergence of several recitation congregations such as those in the recitation group of Jalatunda and Jamuna (the congregation praised the prophet). The practice of religious

\footnotetext{
32 Husein Al-Habsyi.

33 Husein Al-Habsyi.

34 Martin Bruinessen, Tarekat Naqsyabandiyah Di Indonesia (Bandung: Mizan, 1996).
} 
rituals in Sumberejo, Mranggen has a close relationship with Habib Novel, Solo and Habib Luthfi bin Yahya, Pekalongan. The activities held by this group are quite attractive to people from the surrounding and outside Demakareas. At least, more than 600 congregations attend every time the recitation of shalawat is held.

Before using the shalawat of Simtu al-Durar in 2017, Jalatunda congregations used manāqib Nür al-Burhān, a book containing biographies and stories of Sheikh Abdul Qadir al-jilani. Since 2017 the shalawat used to date is a composition of Habib Ali al-Habsyi which contains praises, prayers, and history about the Prophet Muhammad. The change was based on orders from Habib Luthfi bin Yahya as murshid from the leader of the Jalatunda. One of the informants ${ }^{35}$ of this research explained that by recite shalawat Simtu al-Duror, he felt blessed. He felt blessed because as an ordinary and uneducated person he could be close to important people, the scholars, Habib, and Kiai.

The series of activities in the zikir assembly and Jalatunda prayer begins with the recitation of shalawat Simtu al-Duror, recitation of tahlil, and usually ends with a speech by reading turath, such as Riyad al-Shalihin, the work of Syekh Nawawi Banten, then ends with a prayer. The congregation interpreted this series of activities differently. Some interpret the series of activities as a medium for prayer and remembrance, as an expression of love for the Prophet, as a medium for spread out (syi'ar) Islam and a means of worship, and as a medium for gathering.

During the Covid-19 outbreak, in every event that was held, worshipers were strictly prohibited from wearing masks, even if they continued to wear them, they would be forced to return home. One of the informants ${ }^{36}$ said that those who come to pray are physically and mentally pure and clean. Physically they prepare themselves by bathing, performing ablution, wearing clean clothes and fragrances. They prepare inwardly only to get closer to Allah. In addition, the leaders of the congregation said that this assembly was not for people who were afraid of death and that Allah would provide their needs at least if he could only memorize one satar.

Such practices raise the question, why, as the head of the assembly, they didn't campaign for health protocols, as recommended by the government? In the mystical tradition, this can be explained that a leader or teacher (murshid) of a

\footnotetext{
35 Muhammad Hanif, "Interview."

36 Hanif.
} 
congregation has a higher spirituality than an ordinary congregation. In Sufi teachings, murshid is people who are chosen by their teachers to make their groups or assemblies because they are considered to have a clean soul, inner experience so that their characteristics are very visible. Their submission only to Allah makes them only believe in the power of God. In the view of the teacher, the disease is a creature of God who does not need to be feared, it is enough to surrender themselves to God, they believe it can bring salvation.

The phrase "not afraid of death" for the congregation cannot be interpreted superficially. They interpreted it as a guide for life. This means that humans in the world are creatures, created by God, so there is no place to surrender except to Him. In Islamic teachings, there is a belief in destiny which becomes the supporting structure for a Muslim's faith. Faith in destiny is their main asset in living life. Obedience and acceptance of destiny is a form of a Muslim's readiness to die anytime and anywhere.

Apart from internal individual factors, a factor that plays a significant role in the congregation's perception regarding Covid-19 is the role of the leader or murshid. They are considered experienced people in the mystical world. The assumption is that if the congregation wants to get a position like a murshid, then they must follow the murshid's orders. The conception of a teacher's (murshid) honor is the pinnacle of Islam. Manners are the first before science, this is a slogan that is used as a basic guideline for someone who wants to seek knowledge. 37 Submitting to them is glorious and glorified, all orders must be heeded. Some members of the congregation may be people who are obedient people to the health protocol in their daily lives, but again that the murshid's orders are nonnegotiable.

Another aspect is the belief in blessings in prayer. Such belief is more or less the same as the concept in other religions, but with different nomenclature. As for the side of the similarity, a blessing is something good as a result of good deeds or actions that have been done. So it is not surprising that the concept of blessing, especially in Islam, has a vital role in its ability to mobilize human thought to act following religious, ethical, and moral rules. ${ }^{38}$

37 Badruddin Ibrahim, “Tazkirah Al-Saami' Wa Al-Mutakallim Fii Adab Al-'aalim Wa Al Muta'allim” (Daar al-Basya'ir al-Islamiyah, 2016).

38 Sartini Ahimsa-Putra, Al Makin, and Heddy Shri, "A Preliminary Survey on Islamic Mysticism in Java'," Analisis XVI, no. 2 (2016). 
In the implementation of the activities of the Simtu al-Duror prayer council, the congregation who attended was very large and there was a great potential for the spread of Covid-19. However, the activity continued solemnly and the leader of the congregation emphasized that no one was affected by Covid-19, because of the sanctity of their intentions and the sanctity of their assembly. ${ }^{39}$

Inner cleanliness in the mystical dimension is the most important thing. All of these beliefs lead to the concept of Sufism which promotes supra-rational thinking. This thinking ignores all empirical and logical thought. Mystical is a subjective experience that cannot be communicated, it is a type of hudhuri knowledge ( very personal and must be felt subjectively). This mystical experience is difficult to conceptualize in terms of understanding the general public, It has a distinctive language, Ha'iri ${ }^{40}$ called it al-syathiyyat al-shufiyyah. Schimmel ${ }^{41}$ said mysticism is more of an attempt to control or direct oneself. Islamic mysticism is an esoteric method used to get closer to God, the Creator. Sufism teaches its followers to cleanse themselves from sin and all that is forbidden by God and to be aware on earth of good actions and attitudes. Sufism directs its followers to base their behaviour on the love of God, with the view that this love will enable humans to love others.

This research shows that the congregation believes that the shalawat Simtu al-Durar has a positive impact on their social life. Participation in the assembly makes the hearts and minds of the congregation calmer. Every day in the world of work makes people only focus on worldly possessions, with the shalawat congregations they felt to be calm.

The mystical practices of these people have been especially discussed by practitioners. They argue that religious rituals are incapable of bringing about truly meaningful religious practices. It is this lack of meaning that encourages them, including Muslims, to follow mysticism. The activities of the organization or group of shalawat congregations are deemed sufficient to meet the needs of members to communicate intensively through the association. They can care for

\footnotetext{
${ }^{39}$ Hanif, "Interview : Agus Hanif."

40 Mehdi Ha'iri Yazdi, Prinsip-Prinsip Epistemologis Dalam Filsafat Islam Dari Suhrawardi Vis Wittgenstein, Terj: Ahsin Muhammad (Jakarta: Paramadina, 2010).

${ }^{41}$ Ahimsa-Putra, Makin, and Shri, “A Preliminary Survey on Islamic Mysticism in Java'.”
} 
one another, accept good leadership, defend their group, and find satisfaction in their religious practice.42

They believe, people who practice shalawat and join the dhikr assembly will get benefits, not only sustenance but also health and safety. The following is information obtained from a member of the congregation. ${ }^{43}$ They think that people who get the disease are caused by weak immune systems. The body's immunity is weakened due to weakened faith factors. People today are too worried about Covid-19 and ignore themselves, eventually their immunity decreases, this then causes disease. The congregation believes that experts get their intake of faith at all times as a fortress to strengthen the immunity of Covid19 will not attack people who are experts in shalawat and pray.

In spirituality, there are at least two aspects namely faith and practice. The dimension of faith, involves spiritual belief from invisible activities, for example, feeling a close relationship with God. Psychologically, the members of the shalawat Simtu al-Duror congregation get the stability and determination that the prayer they read has brought them to a certain level, to be close to God. This perception is what creates the imaginative impulse that God will not inflict harm, such as disease, on anyone close to Him. ${ }^{44}$ Whereas in the as[ect of practices is characterized by spiritual activities it can be observed as well as involving religious materials or attending worship services, referring to the activities that the congregation do.

Submission or tawadhu to God's destiny and their belief in their closeness to Him are logical reasons why those who have a similar tradition of reciting shalawat are not at all afraid of the infected by Covid-19 and appear to be ignorant of health protocols. Even though this aspect of belief is difficult to examined empirically, a very clear psyche, spiritual breadth, and flexibility make the practitioners of the shalawat tradition seem to be at a safe point, thus creating mental calm. This is what is then rational in the medical world, namely calm, mental health affects physical health. Immune will be formed when the body has a positive response, whether it comes from happiness, calmness, and even Sufistic

\footnotetext{
42 Umar Faruq Thohir, "Pemikiran Mistisisme Annemarie Schimmel,” Ulul Albab 13, no. 2 (2012).

43 Ahmad, "Interview: Ahmad."

${ }^{44} \mathrm{P}$, Thirsty for God: A Brief History of Christian Spirituality.
} 
experiences like the case today. ${ }^{45}$ If traced further, the spiritual resilience experienced in this case is the influence of religious teachings, because religion also contributes to giving inner stability, a sense of protection, happiness, satisfaction, and a sense of success. Apart from being a motivation, religion also contains ethical values and expectations. Religion is the main mouthpiece for the formation of mystical activities that encourage the spirituality of its adherents to increase.

Ibn Sina recommends keeping yourself physically and mentally healthy ${ }^{46}$, first, panic or worry is half a disease. Worry is generally understood as an attack that arises suddenly as a result of fear and is psychologically disturbing. Fear itself can arise because there is a real threat or just because you think too badly and irrationally, aka delusional. Ibn Sina explained that one should not be panic easily in any situation, whether it is safe or dangerous, because panic itself is part of a psychological problem that can have a direct impact on the emergence of physical ailments such as heart attacks, hypertension, and so on. This parallels the understanding of modern medical science that healthy psychology will have a positive impact on the immune system. ${ }^{47}$

In times of crisis like this due to the threat of the Covid-19 pandemic, an attitude of guarding oneself so as not to worry needs to be done with various approaches such as a theological approach and a rational scientific approach. Religion teaches that when a person dies has been established by Allah long before his birth into the world. This must be the belief of every Muslim so that no matter how great the threat of Covid-19 will not threaten someone's life if Allah has not wanted him to die. By faith, it should be, but Islam is not only about faith. Islam is also about sharia, where every Muslim is obliged to endeavor by taking a careful attitude in dealing with something that endangers life. The method of rational scientific approach must also be taken, which is healthy lifestyle and adherence to health protocols. Always think positively that Allah will protect those who surrender to Him. Positive Thinking will also keep someone from feeling worried even though they hear or read scary news both in mainstream

45 Naomi Kalish, "Evidence-Based Spiritual Care: A Literature Review.," Current Opinion in Supportive and Palliative Care 6, no. 2 (June 2012): 242-46, https://doi.org/10.1097/ SPC.0b013e328353811c.

${ }^{46}$ Musthofa Husni, Athlas Lin Nashri Wal Intaji Wal I'lamiy, 1st edition(Kairo: Daar al-Fikr, 2015).

47 Annina Seiler, Christopher P Fagundes, and Lisa M Christian, "The Impact of Everyday Stressors on the Immune System and Health," in Stress Challenges and Immunity in Space, 2020, https://doi.org/10.1007/978-3-030-16996-1_6. 
media and social media about the ferocity of the Covid-19 outbreak which has claimed the lives of thousands of people. ${ }^{48}$

Second, Serenity is half the medicine. Ibn Sina explained the need for people to have calm, both sick and healthy conditions. In a healthy condition, a person who has peace of mind is not susceptible to various physical and spiritual ailments because tranquillity itself is a fortress so that they have strong immunity. Calmness will be easily achieved also through various approaches, namely the theological approach and the rational scientific approach. Al-Quran reminds us of the importance of remembrance of Allah because always remembering Allah will produce a strong inner calm as Allah says: "Remember, only by remembering Allah is the heart calm (Surah Ar-Ra'd: 28)"

Those who always remember Allah in the true sense must have peace because he is so close to Allah that he believes Allah is always taking care of them. This is generally the same across various beliefs and religions, there is a spiritual aspect that makes people feel at peace. This calmness is already half the medicine he needs when he is sick because Allah is willing him to be. In other words, a person who has inner peace because of his closeness to Allah will recover faster from his illness than a person who is always restless and anxious because he does not have good morals to Allah, that is, never remembers Him.

In times of crisis like today, anyone must have patience with the Covid-19 outbreak. One must be patient with various restrictions from various authorities, whether related to health, social, political, educational, economic, or even religious problems. It is impossible for those who are authorized and have competence in their respective fields to intend to lead to society for which they are responsible. With the patience of various parties, both from regulators and from the community who must comply with these regulations.

The concept that Ibn Sina offers is a spiritual endeavour. Such conception is important because the problem of diseases such as Covid-19 is not sufficient to only be seen from a material perspective, but must also involve a spiritual perspective because humans consist of two elements, physical and spiritual. Physical endeavours must be undertaken as they should. Likewise, spiritual endeavours such as calmness by strengthening the side of faith (destiny), the side

${ }^{48}$ Amal I Khalil, Rawan E Nasr, and Rahaf E Enar, "Relationship between Stress, Immune System, and Pandemics of Coronaviruses' COVID19: Updates Narrative Review," European Journal of Molecular \& Clinical Medicine 7, no. 10 (2020). 
of morals (tawaka), and the side of sharia (patience in carrying out endeavours and prayers) must also be emphasized.

Field research on the Jalatunda congregation shows that the shalawat simtu al-Durar framed by Islamic mysticism has shaped the congregation's perception of Covid-19 and built spiritual resilience for the members. Mysticism in religious teachings provides psychological strength and a positive impact on congregation members. If we look at it philosophically, shalawat is only reading, but the mystical power that exists in the human soul has brought spirituality to life in humans. Mysticism is a psychological symptom that comes from a series of human activities. It can be from any teachings or beliefs that can increase spirituality. ${ }^{49}$

Mysticism has positive and useful effects on the spirituality and morality of the individuals involved. Mysticism reaffirms morality by strengthening the attitudes and dispositions of practitioners with moral consequences, including charity, peace, the ability to be influenced, and recognition of transcendental truths. ${ }^{50}$ Mysticism, both as a familiar and influential part of individual religious life and as aesthetics and practice, is the mentality in which people recognize the Ultimate Reality through prayer, aesthetics, and contemplatives. Mysticism brings the people involved closer to the ultimate reality, supports the development of social creativity, and remains firmly entrenched at the heart of religion. This shows the unity of social and religious activities. Humans have emotional expressions. Mystics, meanwhile, have an expression of divinity that directs all energy and thoughts towards God. The energy that comes from this subjective experience is a very important component of shaping one's spirituality.

The mysticism of the shalawat Simtu al-Durar as an individual experience merged into the religion is the basis of branching from the thoughts of the congregation. The roots of mystical experience can be found in union with something sublime, in the recognition of something numinous which is timeless, transcendent, and offers intensified meaning. The mystic who has studied diligently and is obedient will find himself approaching a divine state. In such

${ }^{49}$ Yazdi, Prinsip-Prinsip Epistemologis Dalam Filsafat Islam Dari Suhrawardi Vis Wittgenstein, Terj: Ahsin Muhammad.

50 William J Wainwright, “Morality and Mysticism,'” The Journal of Religious Ethics 4, no. 1 (1976). 
conditions, mystics consider themselves to feel, touch, even become one with God. 51

Mystical experiences also develop self-ness, open channels with others, and allow for the closest of interpersonal relationships and the deepest and truest interpersonal bonds. Therefore, friendship, love, and harmony are characteristics of mysticism. In mystical practice, there is a sense of sanctity about reality, as well as an inexplicable end. Thus, it can be concluded that mysticism, along with spirituality, builds bridges between personality and person, individual and society, human and divine.

Mysticism, as a spiritual experience, influences morality, even among practitioners of different religions. Mysticism is seen as an attempt to gain a deeper understanding of religion and value substance over the form. It is this esoteric dimension of religion that enables the dialogue between different religions and the elimination of religious divisions. In this case, religion is understood to have two dimensions, first is formal, which deals with worldly dimensions and symbols. Second, exoteric deals with the substance of religion including mysticism.

\section{Conclution}

This study found the community practising shalawat Simtu al-Durar framed it with mysticism in it. The belief has it will improve the spirituality of the congregation. They also believe that by recite shalawat Simtu al-Durar, they will be saved from the impact of the covid-19 outbreak. Such perception came, when there is a situation that can not be controlled by a human, then we must get closer to the one who controls the disease, Allah SWT. The mystical and spiritual experiences and values in dealing with the Covid-19 outbreak as a blessing from the practice of the shalawat Simtu al-Durar prayer. However, belief in mysticism is only one aspect that supports spirituality, there are many elements in it, such as personal, divine, and social. This finding also confirms the plural variants of society in Java.

51 Julie Kane, "Varieties of Mystical Experience in the Writings of Virginia Woolf," TwentiethCentury Literature 41, no. 4 (1995): 328-49, http://www.jstor.org/stable/441534. 


\section{Bibliography}

Ahimsa-Putra, Sartini, Al Makin, and Heddy Shri. "A Preliminary Survey on Islamic Mysticism in Java'." Analisis XVI, no. 2 (2016).

Ahmad. "Interview : Ahmad." 2021.

Al-Qurthubi, Muhammad bin Ahmad. Al-Jami'Li Ahkam Al-Qur'an, Jilid VII. Vol. VII. Kairo, 2010.

Alawiy, Sayyid Muhammad.Jala'u Al-Afham Syarh 'Aqidah Al-'awam, 2004.

Ar-Razi, Fakhrudin. Mafaatih Al-Ghaib, Jilid XXV. Beirut: Daar al-Fikr, 1981.

Bruinessen, Martin. TarekatNaqsyabandiyah Di Indonesia. Bandung: Mizan, 1996.

Chapra, Umer. Peradaban Muslim: Penyebab Keruntuhan Dan Perlunya Reformasi. Jakarta: Amzah, 2010.

Collins, Randal. "H. Paul Douglas Lecture the Four M's of Religion: Magic, Membership, Morality and Mysticism'." Review of Religious Research 50 (2008).

Findlay, John. "The Logic of Mysticism.” Religious Studies 2, no. 2 (1967): 153.

Geels, Antoon. Subud and the Javanese Mystical Tradition. Richmond, Surrey: Curzon, 1997.

Geertz, Clifford. Priyayi Dalam Masyarakat Jawa. Bandung: Dunia Pustaka Jaya, 1981.

Hajjaj, Muhammad Fauqi. Tasawuf Islam \& Akhlak. Jakarta: Amzah, 2011.

Hanif, Agus. "Interview : Agus Hanif.” 2021.

Husein Al-Habsyi, Ali. “Untaian Mutiara Kisah Kelahiran Manusia Utama: Akhlak.” Solo, 1992.

Husni, Musthofa. Athlas Lin Nashri Wal Intaji Wal I'lamiy. 1st edn. Kairo: Daar alFikr, 2015.

Ibrahim, Badruddin. "Tazkirah Al-Saami' Wa Al-Mutakallim Fii Adab Al-'aalim Wa Al Muta'allim." Daar al-Basya'ir al-Islamiyah, 2016.

Kalish, Naomi. "Evidence-Based Spiritual Care: A Literature Review." Current Opinion in Supportive and Palliative Care 6, no. 2 (June 2012): 242-46. https://doi.org/10.1097/SPC.0b013e328353811c. 
Kane, Julie. "Varieties of Mystical Experience in the Writings of Virginia Woolf." Twentieth-Century Literature 41, no. 4 (1995): 328-49. http://www.jstor.org/stable/441534.

Khalil, Amal I, Rawan E Nasr, and Rahaf E Enar. "Relationship between Stress, Immune System, and Pandemics of Coronaviruses' COVID19: Updates Narrative Review." European Journal of Molecular \& Clinical Medicine 7, no. 10 (2020).

Khalil, Umi Azizah. Shollu 'Alan Nabi. Yogyakarta: Araska, 2020.

Koentjaraningrat. Kebudayaan Jawa. Jakarta: Balai Pustaka, 1984.

Kuntowijoyo. Dinamika Sejarah Umat Islam Indonesia. Yogyakarta: Pustaka Pelajar, 1994.

- - Muslim Tanpa Masjid. IRCiSoD, 2018. https://books. google.co.id/books?id=4J6sDwAAQBAJ.

Lie, Halie Daniel. “Analisa Kritis Terhadap Pandangan Unio Mystica Ditinjau Dari Teologi Perjanjian Baru.". Veritas 2, no. 3 (2001).

Madrah, Muna Yastuti, Nailil Muna, and Tali Tulab. "Pandemik Dalam Masyarakat Risiko." Wahana Akademika 8, no. 1 (2021): 57-69.

Morissan. Teori Komunikasi Individu Hingga Massa. Jakarta: Kencana Media Group, 2013.

Muhammad Khalid Tsabit. "Tarikh Al-Ihtifal Bi-Maulid Al-Nabi Shalla Allahu 'Alaihi Wa Sallama Wa Madhahirihi Fi Al-'Alam." Kairo: Daar al-Maqtham wa al-Nasyr wa al-Tauzi, 2010.

Muhammad, Sayyid Syarif Abdullah. Al-Nafkhah Al-Ilahiah. Jakarta: Daar ArRaudha Al-Islamiyah, 2018.

Mulyana, Deddy. Metodologi Penelitian Kualitatif. Bandung: Remaja Rosdakarya, 2004.

Nasution, Harun. Falsafat Dan Mistisisme Dalam Islam. Jakarta: Bulan Bintang, 1995.

P, Holt B. Thirsty for God: A Brief History of Christian Spirituality. Minneapolis: Fortress Press, 2006.

Piedmont, L, Teresa A Wilkins, and Ralph L. An Epistemological Approach to 
Understanding Spirituality and the Numinous. 1st edn. New York: Routledge, 2019.

Seiler, Annina, Christopher P Fagundes, and Lisa M Christian. "The Impact of Everyday Stressors on the Immune System and Health." In Stress Challenges and Immunity in Space, 2020. https://doi.org/10.1007/978-3-030-169961_6.

Simuh, Sufisme Jawa Transformasi Tasawuf Islam Ke Mistik Jawa. Sufisme Jawa Transformasi Tasawuf Islam Ke Mistik Jawa. 2nd edn. Yogyakarta: Bentang Budaya, 1996.

Stange, Paul. Kejawen Modern: Hakikat Dalam Penghayatan Sumarah. Yogyakarta: LKiS, 2009.

Subagya, Rachmat. Agama Asli Indonesia. 1st edn. Jakarta: Yayasan Cipta Loka Caraka, 1961.

Thohir, Umar Faruq. “Pemikiran Mistisisme Annemarie Schimmel.” Ulul Albab 13, no. 2 (2012).

Wainwright, William J. "Morality and Mysticism'.” The Journal of Religious Ethics 4, no. 1 (1976).

Wargadinata, Wildana. Spiritual Salawat. Malang: UIN -MALIKI Press, 2010.

Yazdi, Mehdi Ha'iri. Prinsip-Prinsip Epistemologis Dalam Filsafat Islam Dari Suhrawardi Vis Wittgenstein, Terj: Ahsin Muhammad. Jakarta: Paramadina, 2010.

Zawawi. “Interview : Zawawi.” 2021. 